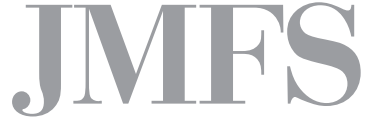

Journal of Management and Financial Sciences
Volume XI

Issue 31 (March 2018)

pp. $9-26$

Warsaw School of Economics

Collegium of Management and Finance

Bogdan Nogalski

WSB University in Gdańsk, Faculty of Finance and Management

Przemysław Niewiadomski

University of Zielona Góra, Faculty of Economics and Management

Agnieszka Szpitter

University of Gdansk, Faculty of Management

\title{
Creativity in the Aspect of Composition of Business Models of Manufacturers from the Agricultural Machines Sector: An Attempt to Assess the Significance of the Requirements
}

"We tell people that if nobody has mocked even one thought of theirs, this means that they are not creative enough"

Bill GATES

ABSTRACT

As a consequence of broad recognition of creativity as an element related to the development of business models under the conditions of a variable environment that is difficult to forecast, it has been appreciated by management sciences. In the context of the above, research was commenced in order to attempt to provide an answer to the question: is the scope and type of business models implemented by manufacturers a derivative of the creativity level assimilated by them?

In connection with the above, it was necessary to:

- from the theoretical perspective - using the method of reconstruction and interpretation of the Polish and foreign literature on the subject - present creativity as a factor contributing dynamics to the development of business models; 
- from the design perspective - determine which business models are adopted by micro, small and medium-sized production enterprises operating in the Polish farm machines sector;

- from the empirical perspective - establish to what extent implementation of the mentioned business models is determined by creativity desired by manufacturers.

This publication has been created as an effect of the authors' thoughts and searches; first of all, their practical experience and activity in management practice.

Keywords: creativity, flexible business models, strategy, agricultural machinery sector JEL Classification Codes: M530, M510, L620, O340

\section{Introduction}

Currently, it is a good moment for a discussion concerning different aspects of creativity of Polish enterprises ${ }^{1}$ and determination of its impact on the business models implemented by them. ${ }^{2}$ These considerations, in the opinion of the authors, should motivate entrepreneurs to compose them as appropriate - as necessary, to reduce the level of difficulty in undertaking and performing adaptation processes, reduce the degree of risk and uncertainty as well as help to make optimal choices for entrepreneurs who are not entirely familiar with the mechanisms of their introduction.

The issue concerning business models is a new and very interesting subject area in management sciences, ${ }^{3}$ the more so that the present times are characterized by deep social and structural transformations in the global dimension, strongly determining all business actions being undertaken. Enterprises seeking to succeed on the market must meet the requirements of the contemporary economy that can be characterized by networking, high volatility of the operating conditions and rapid development of new technologies. This means that organizations, and, in fact, their managers, face difficult challenges, which should be addressed. ${ }^{4}$

1 The study refers to production enterprises involved in the manufacturing of agricultural parts and machines. They are the subjects of the present and future research of the authors. In the opinion of the authors the enterprises subjected to the study - under the conditions of no stability - in order to generate value for the customer, are characterized by the need to follow adaptation processes with regard to the existing business models. See: [Nogalski, Szpitter, Jabłoński, 2016, p. 60]. Limiting research to one subject (enterprises from the selected sector) results from the fact that comparability of the results has to be restricted to one type of subjects. After [Romanowska, 2016, p. 219].

2 The selected aspects of creativity are discussed in the papers of T. Amabile and M. Khaire. See: [Amabile, 1983, pp. 997-1013; Amabile, 1988, pp. 123-167; Amabile, 1996; Amabile, Khaire, 2008].

3 The subject matter of business models is many times discussed under the sessions - of the conference annually organized by Wojciech Korfanty Upper Silesian Higher School of Commerce - Conference of Management Science Professors.

$4 \mathrm{M}$. Romanowska notices that the selection of the strategic attributes results from determination of the strategic goals of the organization. See: [Romanowska, 2014, p. 89]. 
In contemporary management sciences, the thesis is formulated about a key role of innovation and creativity in shaping the success of the organization. This issue gains particular significance especially under the conditions of the development of knowledge-based economy sectors, ${ }^{5}$ in which the ability to devise new solutions to the already existing problems, the ability to generate new and valuable ideas and concepts is becoming a key factor of growth, both in micro- and macroeconomic scale.

The problem area concerning creativity in management is currently a catchy topic and the subject of interest of many researchers; it is not a new area. ${ }^{6}$ The study of the literature in question from the recent years indicates that attempts to characterize creativity (creativeness) have been taken up many times [Andriopoulos, Dawson, 2011; Augsdorfer, Bessant, Möslein, 2012; Bilton, Cummings, 2010; Bratnicka, 2010; Bratnicka, 2011; Bratnicka, 2014; Bratnicki, Bratnicka, 2011; Bieniok, 2014; Brzeziński, 2009; Kuhn, 1989; Niedzielski, Rychlik, 2006; Leigh, 2011; Nęcka, 2005]. This characteristic, being a mix of adequate competences and attributes, may be understood as a dynamic capability, being the basis for the business model of the most effective organizations. In this study, creativity is identified with creation understood as the ability to generate (invent) new and valuable ideas (ideas, concepts, solutions).

The application of the business model in farm machine production enterprises, an attempt to support the business management process by this concept, requires creative behaviour. The analysis of the subject literature shows that such a concept requires adjustment to the specific nature of the particular sector. Meanwhile, research works have not been taken up so far in order to arrange in a comprehensive way the knowledge about the business models, focusing only on the description and diagnosis of creative behaviours [Bratnicka, 2016, p. 83]. The noticed and above described gaps in knowledge have created a problem situation and have become a motive for the authors to undertake research on creativity in the aspect of composition of the business model. It has inspired the authors to conduct a cycle of research, the subject matter of which was the ability of Polish production enterprises from the agricultural machines sector to create new solutions or generate new, valuable concepts and ideas.

As a consequence of a broad recognition of the importance of creativity as an element related to the development of business models under the conditions of a variable environment that is difficult to forecast, it has been appreciated by management sciences. It is thanks to the creative behaviours that the organization can quickly respond to changes in the complex and turbulent environment, in which it is necessary to develop new business models as adequate to the needs. In the context of the above, research was started to attempt to answer the question: Is the scope and type of business models implemented by the manufacturers a derivative of the creativity level assimilated by them? In other words, to which degree is the composition of

5 Organizations focused on knowledge management - W. Dyduch and M. Bratnicki call them intelligent. See: [Dyduch, Bratnicki, 2016, p. 10]. This view is fully shared by the authors of this work, who stress the need for incorporating creativity processes into strategy and supporting the participants of the intelligent organization with regard to reporting new and useful ideas.

6 Among many researchers involved in the problem area of creativeness or creativity in Poland, the works by W. Dyduch should be distinguished. See: [Dyduch, 2013; Dyduch, 2014]. 
the selected business models determined by the ability, desired by the manufacturers, to devise new solutions to the already open problems, to generate new and valuable ideas and concepts?

In connection with the above, it has been necessary in this work, being fragmentary and not yet being a full verification of the authors' research concerning formulation of business models, to:

- from the theoretical perspective - using the method of reconstruction and interpretation of the Polish and foreign literature on the subject - present the ways, related to many areas, of the conceptualization of creativity as a factor contributing dynamics to the development of business models; ${ }^{7}$

- from the design perspective - determine which business models are adopted by micro, small and medium-sized production enterprises operating in the Polish farm machines sector; using the method of reconstruction and interpretation of the subject literature supported by discussion among the selected experts, the authors wanted to present a list of the business models composed by enterprises from the examined sector;

- from the empirical perspective - the intention of the authors is to determine to which extent the implementation of the mentioned business models is determined by creativity desired by the manufacturers.

This publication has been created as an effect of the authors' thoughts and searches; first of all, their practical experience and activity in management practice. In the opinion of the authors, the study should reduce the degree of risk and uncertainty as well as help to make an optimal selection of the business model for entrepreneurs who are not entirely familiar with the mechanisms of its implementation.

\section{Creativity in management theory and practice: literature overview}

Under the conditions of variable environment, the issue of creative business management becomes not only a domain of theoretical interests, but a guideline for managers in building new business models. ${ }^{8}$ Contemporary enterprises must cope with the demand for custommade products, which forces exceptional solutions especially with regard to the organization of manufacturing processes. Therefore, it can be noticed that the most valuable skill of contemporary organizations becomes the ability to create and implement new ideas with regard to non-standard solutions. The success of the organization has ceased to be only a result of skillful investment and use of capital. A predominant conviction among practitioners is that

7 The authors undertake a theoretical reflection providing guidance for managers' actions, especially that the product of management sciences should be the creation of the explanatory theory. More thoroughly: [Czakon, 2017, p. 143].

8 The more so that many complex processes are taking place inside every organization. After: [Wachowiak, Gregorczyk, Majewski, 2014, p. 364]. 
competitive advantage is achieved as a result of unique solutions. In connection with the above, it can be noticed that the most valuable skill of contemporary organizations is the ability to dynamically create and implement new business models.

Creativity, in the opinion of the authors of this paper, has always been associated with innovation, which is often called creativity or originality of solutions [Nogalski, Niewiadomski, 2016, p. 118]. The innovation of an organization stems from creative ideas. The development of new ideas, going beyond the present state of affairs, is, after all, a precondition for the implementation of new products [Andriopoulos, Dawson, 2011; Damanpour, Aravind, 2012]. According to some authors, creativity differs, however, from innovative activity in that the latter concentrates not so much on generation of creative ideas as on their introduction to reality [Szpitter, 2010, pp. 350-365]. Good innovation - through effective implementation of creative ideas - creates value added for the organization. From this perspective, creativity refers to the entity's activity, to their empowering activity bringing new value. The essence of creativity, as an important feature of an innovative enterprise is ideation, namely the ability to devise many solutions to open problems, to generate new and valuable ideas and concepts of running the business. ${ }^{9}$

The above seems to be confirmed by J. D. Antoszkiewicz [2008, p. 9], noticing that creation of an innovation consists of two human activities: creativity, which leads to finding an idea for a better solution to the problem and entrepreneurship, due to which ideas are materialized, obtaining its place in the business, social or political reality. ${ }^{10}$

The analysis of the subject literature allows clearly stating that "creativity" is a term being a multi-dimensional notion, which results in difficulties in clear interpretation, both by authors representing management sciences and related sciences. The notion of creativity owes its popularity to the search for new solutions to tackle the challenges that are faced by businesses in connection with the growing global competition, or treatment of knowledge and information as the potential that enables more effective competition on the market. In the opinion of the authors of the paper, creativity is disclosed in activities that are a sequence of certain capabilities. In view of the foregoing, they are of dynamic nature. Identification of creativity with skills is the right thing for an organization operating in the present economic reality, an organization which runs out into the future, gains new knowledge, stimulates intellectual curiosity as well as encourages discussion.

When considering the terminological context of the creativity notion, as compared to capabilities, it should be emphasized that, to be creative, it is necessary to acquire specified capabilities. A creative enterprise is capable of using its knowledge, skills and dispositions as well as personal characteristics of the employees, so as to achieve goals. A creative company

${ }_{9}^{9}$ At this point, it is worth emphasizing that creativity may be manifested at a high level in various phases of development of the enterprise.

10 From the point of view of business operations, creativity itself has little value, unless it is reflected in implementing new products, services, or processes. Consequently, one should not be surprised by the notion of creativeness being used in the context of the organization, as it encompasses both creativeness and innovation. After: [Bratnicka, 2014, p. 30]. 
is one that, as a result of a proper attitude and behaviours, will be able to positively use their knowledge resources, and capabilities. In view of the foregoing, it may be assumed that the creativity level is dependent on competences, which include knowledge, experience current information and their context, capabilities and the ability to use them, and finally the attitude itself, motivation, behaviours and values.

Creativity implies the ability to re-allocate production resources so as to produce effectively, without unnecessary wastage, ensuring acceptable quality. In the short term this means the ability to adapt to the changing conditions with the use of the existing resources. In the long term this is the ability to introduce new products, new resources and production methods and their integration with the existing production systems. Key here is the ability of the production system to change or react, while incurring small outlays from the point of view of time, cost or results of operations.

In the context of the above, the fact worth paying attention to is that creativity is a feature which should characterize enterprises operating in the new conditions of the business environment and seeking to survive in it. Creativity makes it possible to use the methods, production and organizational processes, practices and tools, the majority of which has been developed to quite a little extent so far.

Due to continuous and fluctuating variability of the conditions, businesses must develop new features, behaviours and attitudes, which will constitute an adequate and effective response to the globally transforming reality [Nogalski, Szpitter, 2017, pp. 197-210]. This means that a significant characteristic of the present times is recognition of creativity as a critical factor, decisive for survival or development of the organization, and creative management becomes (in the conditions of uncertainty and dynamic changes) an instrument opening new horizons for the enterprise in the form of the composed business models.

In order to make judgments about the reality, phenomena, processes related to the generally understood management, the scope of the notions implied by the conducted research should be clearly defined. Since the term "creativity" often occurs both in common thought as well as in scientific studies, the authors have recognized as reasonably practical to present selected definitions and confront them with the reality. It has made it possible to develop, adopt and consequently apply and understand the term, the more so that it has no precisely set meaning. The attempts to establish a terminological order taken in this study - in a far simplified way - have had only the cognitive value; the intention of the authors was only to capture the areas, approaches and dependencies as implied by the research. To sum up, it should be emphasized that:

- The notion "creativity" is a multi-aspect and complex notion, which results in difficulties in clear definition and interpretation; there is a multiplicity of definitions; ${ }^{11}$

- Most definitions share a common element in the form of value creation for the company;

${ }^{11}$ An interdisciplinary approach to the problems of creativity gives rise to various understandings and definitions of the same term. 
- Creativity is a notion that is strongly correlated with innovation;

- Creativity can be considered from different perspectives, noticing it within the individual (creativity of employees) as well as across the entire organization;

- With regard to the interpretation of the notion, transfer of scientific achievements from other countries or sciences is sometimes observed without any clear indication of the origin and the meaning of the definitions being discussed;

- Some authors regard creativity and innovation as identical notions; ${ }^{12}$

- In the subject literature there is no consent with regard to the relations between the both terms; opinions about the superior character of one over the other can be found;

- Management theory and practice shows that there is a long way ahead before adopting one, commonly accepted definition of the term "creativity", 13

- As a consequence of a broad recognition of the importance of creativity under the conditions of variable environment that is difficult to forecast, it has been appreciated by management sciences.

Undoubtedly, the methodological confusion has developed that sometimes leads to contradictory opinions, or even disputes concerning what creativity is indeed, and therefore, what methods should be used to measure it. ${ }^{14}$

Tu sum up the discussion concerning creativity, it is important to ensure that, when referring to other authors, while transferring and comparing experience of various researchers, attention should be paid to the interpretation of this term by the given author. From the analytic point of view, it is important that the adopted definition should serve well the research goals.

\section{Material and research method}

In the course of the conducted research, the authors make an attempt to answer the question: is the scope and type of the business models implemented by the manufacturers a derivative of the creativity level assimilated by them? In other words, to which degree the composition of the mentioned models of running business is determined by the ability, desired by the manufacturers, to devise new solutions to the already open problems, to generate new and valuable ideas and concepts?

12 According to the authors, the notions of creativity and innovation share some similarities. They apply to key aspects of the company's operations whose less important aspects are subordinate to. However, these are not identical notions.

${ }^{13}$ Search for one, common or universal definition would enrich neither knowledge nor practice of management, and, at the same time, could result in narrowing the research field; the authors recommend such definitions that are reasonable in the context of the organization's conditions and may be used consistently in research being conducted.

14 Therefore, the need arises to initiate research in this regard, which will be the subject matter of subsequent studies. In the light of the many attempts with regard to measuring the potential creativity of a manufacturing enterprise, the attempt to outline the management areas implying the enterprise's creativeness should be noticed, initiated by the team of scientists lead by B. Nogalski. 
The experts invited to participate in the research were asked to indicate to which degree the composition of the mentioned business models is determined by creativity. Significance was marked on a 5-point scale, where 1 - low effect of creativity, and 5 - models the implementation of which is determined by a high creativity level. Research results were subject to a simplified statistical processing.

Research methods and tools are quite often used in empirical research (directly or with certain modifications) that have been verified in other research. In the context of the above, the authors of this work did the same, however, the research method and tools were selected according to their own methodological concept. While implementing the preparatory study focused on composing the research model, the authors applied the method of literature studies [LS]. The preparatory study conditioned the conduct of the proper study; the intention of the authors was to prepare a list of pattern business models implemented in practice by the enterprises. The list developed at this stage consisted of 63 business models. ${ }^{15}$ Composing the research model, the currently fullest list of business models was used to a great extent, being the key factor in the success of contemporary enterprises, supplemented by proposals of Polish and foreign authors and selected management practitioners.

Since the exemplification of such a high number of business models strongly complicates and prevents the formulation of important conclusions, the originally prepared list was subject to discussion [B1] among 14 carefully selected experts.

Persons with various competencies and experience were invited to participate in the meeting. The discussion was conducted among 2 intentionally selected representatives of manufacturing companies from the agricultural machines sector (in each case these were professionally active persons, actively participating in the strategic management of the company they come from ( 9 persons - the owners) or which they work for (3- management personnel, 1 - president of the management board, 1 - proxy). ${ }^{16}$ Two stages were separated in the discussion: in the first stage new ideas were reported, trying to open minds to any appearing opportunities and solution options present in practice, in the second one, on the contrary, the suitability was assessed of the business models reported and presented by the authors as present in the literature.

As a result of this research, a list of 37 business models was prepared, most often composed by Polish production companies operating in the farm machines sector. This stage of the research was conducted from $15^{\text {th }}$ to $31^{\text {st }}$ May, 2017. In this way, the tool focused on the conduct of the proper study was prepared [B2].

The second stage of the research was completed on $22^{\text {nd }}-25^{\text {th }}$ September 2017 . The research was conducted at meetings and direct calls during the International Agriculture Exhibition

1555 business models patterns determining success of $90 \%$ of enterprises are discussed in their work by B. Nogalski, A. Szpitter, A. Jabłoński. More thoroughly: [Nogalski, Szpitter, Jabłoński, 2016, pp. 51-59].

16 Starting the research, it was assumed that intuitive thinking in the group of intentionally selected persons may result in creating new ideas, concepts or new associations or linkages with the already existing ideas and concepts; the purpose was to obtain original and realistic solutions. 
AGRO SHOW organized by the Polish Business Chamber of Agricultural Machines and Devices. AGRO SHOW is a platform for expanding knowledge, exchange of views, contacts and experience, which the research authors decided to take advantage of.

Within the framework of the proper study [B2], interviews were conducted among 69 intentionally selected experts representing the intentionally selected enterprises -65 persons $(94.20 \%),{ }^{17}$ scientific institutions -3 persons $(4.35 \%)^{18}$ as well as business support organizations - 1 person $(1.45 \%){ }^{19}$

When making the decision to select the experts (intentional selection), an important criterion was their direct acquaintance with the researchers, supported by partner cooperation with the party of the research - Zakład Produkcji Części Zamiennych i Maszyn Rolniczych "Fortschritt". It made it possible to determine whether the representative of a given enterprise performing the assessment is independent in the presented views and issued opinions, and whether he/she has sufficient knowledge with regard to the undertaken problem area, supported by the grounded position in the industry.

The study was attended by all the invited experts. Considering communication barriers, the persons with whom direct meetings were planned and it was possible to hold a conversation, were invited to the research. The application of the intentional selection technique as well as the possibility of conducting research at the time of business meetings undoubtedly contributed to the high effectiveness and quality of the research.

\section{Results of the authors' research ${ }^{20}$}

Considering the significance level of creativity as a factor determining the composition of business models, they have been divided into two groups, i.e. constitutive (primary) - models significantly implied by the creativity level and not neutral. The authors assumed the following

17 Within the group of management practitioners, the following were invited to the research: a) owners of enterprises - 31 persons (44.93\%); 61.29\% of the owners had higher education, $25.81 \%$ - medium, $12.90 \%$ - professional; 14 persons were more than 50 years old, 9 persons were $40-50$ years old and 8 persons $30-40$ years old), b) managers - 23 persons (33.33\%); the authors included in the group of managers the persons holding managerial functions in the company, but having no more than $10 \%$ ownership interest. $82.61 \%$ of the managers had higher education, 13.04\% medium, $4.35 \%$ professional; 5 persons were more than 50 years old, 9 persons were $40-50$ years old and 8 persons 30-40 years old, 1 person less than 30 years old, c) president of the management board - 2 persons (5.8\%); higher education - one of the experts had a completed MBA course, d) proxy - 1 person (1.45\%); higher education; master engineer: specialization: transport and rail vehicles), e) future successors of enterprises -6 persons (8.7\%). The experts represented the following enterprises: micro - 11 persons $(16.92 \%)$, small - 21 persons $(32.31 \%)$, medium -27 persons (41.54\%) and large - 6 persons (9.23\%). Micro, small and medium-sized enterprises hold a key position in the agricultural machine manufacturers sector, therefore such entities dominated among the entities selected for the research $(90.77 \%)$.

${ }_{18}$ The group of consultants included persons being members of the Scientific Council of the Industrial Institute of Agricultural Machines and a representative of a university specializing in management strategy.

${ }_{19}$ Business Centre Club expert for SME management strategy and innovation development, and science - knowledge - business cooperation.

${ }^{20}$ The authors hope that this publication - at least to a minimum degree - will become the beginning of the discussion on the essence of the effect of creativity on ground-breaking strategies and business models. 
solution: the bottom limit of the values range for the first group was score 4.00. As a result of the conducted research, 27 business models were qualified to this group. The other group of models - not neutral to creativity - were those that obtained scores below 4.00; 10 models were classified to this group.

From the point of view of enterprises taking part in the study a narrow group of customers, looking for a product or service with strictly specified utility properties, is important. Entrepreneurs, aiming at satisfying expectations of this group of recipients - in the opinion of the authors - should follow the strategy of a market niche by concentrating business operations on a specific group of products offered usually to a small group of buyers in a geographically specific market. Such actions make it particularly useful to micro, small and medium-sized companies, which often, not having sufficient amounts of available capital and broad organizational possibilities, compose such business models. ${ }^{21}$ Not undermining the effectiveness of this management model followed by the owners, it can be presumed that such a way of conduct implies a high creativity level, which - in the opinion of the authors - can be used also when running business operations at a large scale (the average score: $4.90 ; 89.9 \%$ of the indications for the 5-point score).

If there are comparable offers of products on the general market, the attribute allowing competitive advantage to be obtained and maintained are innovative activities. However, an innovation niche can be built only when innovation can be "defended", e.g. using patents or licenses. This is an action aimed to protect the enterprise against the market leaders' advantage of scale and gives the possibility to maintain competitive advantage for a longer time. In connection with the above, use of product or process innovations to differentiate (distinguish oneself), being the basis for long-term advantage or development, requires a high potential of creative behaviours from enterprises (the average score: $4.74 ; 75.4 \%$ of the indications for the 5-point score) determining actions taking advantage of opportunities for the enterprise's strategic purposes. In the implementation of activities to actually take advantage of opportunities, an important factor affecting the success of these actions is creativity, since seizing an opportunity is indeed a game without the established rules, which are discovered, verified and used only in its course by the participants of the organization (the average score: 4.72; $73.9 \%$ of the indications for the 5-point score).

In the opinion of the authors, the greatest challenge to be faced by managers in the process of defining or redefining the business model is to configure the value proposal for the client. The task consists in solving an important, from the point of view of the client, problem or satisfying his or her important need. In connection with the above, recently the issue of product innovations has raised a very large interest in business models. Research shows that introduction of changes innovative in nature within the product can give competitive advantage and continuous development to the organization, despite the prevalence of extremely difficult

${ }^{21}$ An additional advantage of applying the niche strategy by businesses is also missing (or restricted scope of) competition in the niche on the part of large companies. 
conditions of running business operations, which will not be guaranteed only by process-related innovations. Implementation of new products requires many barriers to overcome. It seems that the most important barrier is the low creativity level among the top managers who are strongly involved in the previous product portfolio, or even owe their present position to it. ${ }^{22}$ To overcome this problem, concentration solely on the current situation should be avoided, and, in addition, signals cannot be underestimated, which may prove gradually disappearing interest in the present offer.

Implementation flexibility reflected in the approach to the client and his or her needs, which, in the long term, is reflected in deeper relations between the parties, is an important model of running the business being adopted by production companies operating in the Polish farm machines sector. The essence of the so formulated model is creative management implicating a business model focused on production and sale of small quantities of a broad product portfolio (the average score: $4.7 ; 72.5 \%$ of the indications for the 5-point score) and long-term partner attitude, mutual respect and the pursuit of communicating under two-sided relations (the average score: $4.70 ; 7.0 \%$ of the indications for the 5 point-score). therefore, important is the proper reconfiguration of resources creating value for the customer; then competitiveness increases, which is - very strongly - implied by a creative approach to management (the average score: $4.67 ; 68.1 \%$ of the indications for the 5 -point score).

A starting point in the application of the client orientation method is systematic observation of the changing needs and expectations of users as well as verification whether other companies in the given segment already offer such a solution. Creativity in search of new solutions is the basic action at this stage. It is important to focus on cooperation and closely observe fluctuations in market demand. This attitude imposes the need to implement another business model which assumes improvement in the effectiveness of internal and external processes, by their optimization or introduction of new solutions, namely process-related innovations. In the area of the company's internal actions, process-related innovations are intended to ensure organizational excellence and reduce costs incurred by the company. On the other hand, in the area of the company's external actions, process-related innovations are to help to identify opportunities and offer unique products on the newly opening target markets. Such actions require a high creativity level (the average score: $4.48 ; 53.6 \%$ of the indications for the 5-point score).

In the contemporary economy a properly created and promoted brand often turns out to be a source of advantage over competitors and at the same time the company's growth. However, creating a brand itself is not enough - it should be managed, its potential should be used and where necessary - it should be modified as necessary. Only as a result of creative brand management it is possible to fully use its potential (the average score: $4.46 ; 55.1 \%$ of the indications for the 5-point score). As a matter of fact, brands die and disappear from the market,

22 According to experts, the composition of the "unique products model" is significantly implied by creativity (average score $4.72 ; 73.9 \%$ of the indications for the 5-point score). 
if they neglect the need to change or if the company does not develop their potential to cater for its consumers' changing expectations. Using the strength of its brand, creative enterprises introduce products to the market many times using the profit from selling a product, trademark or the utility model implemented much earlier, the so-called profits multiplier model.

Creativity in building a network of strategic relations implies incorporation of external partners into the processes of creating key values, such as research and development of new technologies. Therefore, it constitutes a significant competence which allows the company to discover utility niches for results of the conducted research, either ready or still being formed (the average score: 4.46; 52.2\% of the indications for the 5-point score).

Creativity determining the composition of such a model is declared by the respondents who see the need for systematic observations of the manufacturing technology and the products offered by the main competitors. Creative enterprises make use of the information obtained as a result of the observations in order to prepare a product similar to the competitors' or a compatible one, or the technology of its manufacturing.

However, according to the authors, enterprises should not offer ready-made implementations to their partners; they should work on them together, which is a derivative of a high level of creativity assimilated by them (the average score: $4.43 ; 49.3 \%$ of the indications for the 5-point score).

Creativity determines investing on the newly opening markets (the average score: 4.39; $49.3 \%$ of the indications for the 5-point score) and substantially affects the ability of companies to implement technical non-mass products, including parts and components requiring high precision (the average score: $4.39 ; 42.0 \%$ of the indications for the 5-point score). Management of free solutions not implemented in production, or unused $\mathrm{R}+\mathrm{D}$ potential, mostly through science - business cooperation is also significantly dependent - in the opinion of the experts - on the creativity level of a given company (the average score: $4.38 ; 42.0 \%$ of the indications for the 5-point score).

Creativity very strongly contributes to control and utilization of the key part of the supply chain (the average score: $4.36 ; 44.9 \%$ of the indications for the 5-point score). It is the "creative integrator" which encompasses the whole scope of the production process - from acquisition of raw materials to production and distribution.

According to the examined respondents, creativity is a competence giving the guaranteed availability of the complete range of products (the average score: $4.35 ; 42.0 \%$ of the indications for the 5-point score). Configuring such a business model, the enterprise satisfies all needs of the client in the specific domain. In connection with the dynamically developing product market, for many companies operating in the farm machine sector, production to order is an attractive form of operation. Many companies have focused only on production for the external recipient - both for chains and for manufacturers having their own brands and wanting to broaden the scope of the offered products, but not having the necessary production capacities or technological facilities. The adoption of such a business model requires high creativity (the average score: $4.29 ; 37.7 \%$ of the indications for the 5 -point score). In order to be an attractive 
partner, a production company must have the adequately equipped technological and research facilities, guarantee high quality, logistic or management standards, confirmed by certificates and audits as well as ensure high and repetitive quality of the delivered products.

Very often the product price in reality is not determined by the manufacturer only. The price is shaped by the market and the obligation of the manufacturer is to flexibly adapt to its requirements, often being unattractive. Therefore, it is important to stimulate thinking leading to original and appropriate solutions which will allow the manufacturer to adapt in this respect (the average score: 4.28 ; $44.9 \%$ of the indications for the 5 -point score).

Thus, the readiness for creating new ideas becomes the key attribute to eliminate losses incurred in the waste utilization process - as suggested by the experts participating in the research (the average score: $4.29 ; 36.2 \%$ of the indications for the 5-point score).

The ambitions of companies operating on the market increase along with their growth in the farm machine market. And the greater the ambitions, the greater the requirements concerning service. The new economy needs a new look at their standards. In connection with the above, the e-commerce business model has not been disregarded by the suppliers. In this model, a business party is often the individual client. The manufacturer receives access to a broader group of customers, which requires active sale and appropriate positioning actions. It requires a completely new approach to the customer's needs. International expansion is embedded in the mere idea of e-commerce. Simple sale of a product is out of the question, it is necessary to accurately examine the business, learn the markets on which it operates, which it intends to enter, how it handles returns, where it has accounts, and prepare a proposal based on three pillars: automation of the processes, their centralization and stimulation of the growth potential. A factor significantly determining this model of running the business is the ability to demonstrate creative behaviours (the average score: $4.19 ; 40.6 \%$ of the indications for the 5-point score). A high level of creativity (the average score: $4.17 ; 43.5 \%$ of the indications for the 5-point score) enables correct management of relations with customers, and thanks to dedicating appropriate special offers to them, increases their loyalty. In this context, the essence of creativity manifests itself in current observation and analysis of the competitors' products affecting the ability to optimally use the existing manufacturing technologies (the average score: $4.17 ; 43.5 \%$ of the indications for the 5 -point score).

Customer service is perceived as the skill or ability to satisfy requirements and expectations of customers, mostly as to the time and place of the ordered deliveries, using all available forms of logistic activity, including transport, warehousing, management of inventory, information and packaging. Therefore, the order lead time should be classified as one of the most important factors determining the client's satisfaction; at the same time, it is a competitiveness factor. For this reason, continuity of the material flow should be provided, not only inside enterprises, but also in the whole supply chain. In the context of the above - under the conducted research - it was determined that the pursuit of satisfying the needs of customers at any time is significantly determined by the level of the potential of creative behaviours assimilated by the company (the average score: $4.17 ; 43.5 \%$ of the indications for the 5 -point 
score). It implies a business model which, as assumed, reduces use of the indirect channel; is based on direct delivery of the goods from the manufacturer to the end client (the average score: $4.06 ; 36.2 \%$ of the indications for the 5 -point score).

A relatively high creativity level is also important in the context of the composition of business models focused on key activities and contracting performance of the determined tasks to specialized external entities (the average score: $4.04 ; 36.2 \%$ of the indications for the 5 -point score), ${ }^{23}$ distribution of one's products under other brands (the average score: 4.04; $24.6 \%$ of the indications for the 5-point score), or assuming cost leadership (the average score: $4.01 ; 29.0 \%$ of the indications for the 5 -point score).

The research results presented in Table 1 show that the creativity level assimilated at a slightly lower level (scores below 4.00) adds dynamics also to the composition of the other business models subject to analysis.

Table 1. Creativity as a determinant of business model composition in the opinion of experts

\begin{tabular}{|l|l|c|}
\hline \multicolumn{1}{|c|}{ Model name } & \multicolumn{1}{|c|}{ Characteristics } & Average \\
\hline Barter exchange & $\begin{array}{l}\text { Implementation of solutions based on the exchange of completely different goods } \\
\text { between the parties to the transaction. }\end{array}$ & 3.97 \\
\hline "Green" model & Making effort for an environmentally-friendly image. & 3.94 \\
\hline "Magnet" product & $\begin{array}{l}\text { Additional products, which customers must buy in order to use the basic product, are } \\
\text { expensive and in this way, generate most income (stars). }\end{array}$ & 3.72 \\
\hline $\begin{array}{l}\text { Technological } \\
\text { openness }\end{array}$ & $\begin{array}{l}\text { Incorporating external partners into the processes of creating key values, such as } \\
\text { research and development of new technologies. }\end{array}$ & 3.57 \\
\hline $\begin{array}{l}\text { Operator } \\
\text { Higher quality } \\
\text { - higher price }\end{array}$ & $\begin{array}{l}\text { Enterprises specialized in delivery of only a given group of products, resulting, e.g. from } \\
\text { the ability to run production in specific conditions. }\end{array}$ & 3.51 \\
\hline Production scale & $\begin{array}{l}\text { The customer pays more for a given product than the average market price. In return, } \\
\text { they receive additional value in the form of higher quality of the purchased product. }\end{array}$ & 3.28 \\
\hline $\begin{array}{l}\text { Preventive } \\
\text { to reduction in unit manufacturing costs. }\end{array}$ & $\begin{array}{l}\text { The assumption is reduction in costs incurred as a result of failure of machines and } \\
\text { technical devices, and elimination of downtime. }\end{array}$ & 2.87 \\
\hline $\begin{array}{l}\text { Offered and obtained } \\
\text { merchants' credits }\end{array}$ & $\begin{array}{l}\text { The enterprise generates revenue from the sale of a given product much faster than pays } \\
\text { suppliers for the raw materials and the materials purchased in order to manufacture it. }\end{array}$ & 2.84 \\
\hline $\begin{array}{l}\text { Orchestrator } \\
\text { Concentration on one or just a few activities in the value chain. Most activities within the } \\
\text { value chain are entrusted to specialized suppliers. }\end{array}$ & 2.78 \\
\hline
\end{tabular}

Source: the authors' own elaboration.

The dynamic and often also turbulently changing environment affects change in behaviours of business organizations [Brzóska, Krannich, 2016]. They look for effective methods of competing, by shaping and implementing new strategies and business models, using, to a growing extent, innovations and co-operation in them. It is confirmed by the results of the authors'

${ }^{23}$ It is a model in which enterprises outsource the realization of some phases of the production processes outside the organization, in order to reduce costs, leaving some of the processes related to distribution, creation or design in their area of operation. 
research, in which creativity is a key determinant adding dynamics to the composition of business models implemented by the Polish enterprises from the agricultural machines sector.

\section{Summary}

The main purpose of this work was an attempt to answer the question: is the scope and type of the business models composed by manufacturers a derivative of the creativity level assimilated by them? In other words, to which degree is the implementation of the selected business models determined by the ability, desired by the manufacturers, to devise new solutions or generate valuable ideas and concepts? The above question as well as the conviction about the presence of business demand for applicable results were the main inspirations to undertake the research. In order to achieve the specified goal, partial tasks had to be formulated and attained. In connection with the above, using the method of reconstruction and interpretation of the Polish and foreign subject literature, basic ways of conceptualizing creativity, related to many areas, have been presented. A list of pattern business models, significantly composed and implemented by the production enterprises operating in the farm machine sector, has been outlined.

According to the intention of the authors, the work is supposed to cast light on a wider perspective of generating valuable ideas and concepts in the context of composition of business models.

The presented research constitutes the starting point for improving human resources management processes. The knowledge of the differences between the model and current level of creativity can be used in planning training needs. People responsible for the development of the managerial staff in a given company are presented with specific expectations, which is undoubtedly necessary when creating modular improvement programmes.

The presented research results have determined the direction of the authors' further works that will soon be presented in separate publications. Nevertheless, there is a need for further research into the determinants of the creativity development in the light of shaping the reconfiguration potential of enterprises. It is necessary to try to adapt the concept of an expert system actuating the composition of the business model, and to develop a method for assessing the impact of creative behaviour on the ability and direction of its profiling.

\section{References}

1. Amabile T.M., 1983. Social psychology of creativity: A componential conceptualization. Journal of Personality and Social Psychology, 45, pp. 997-1013.

2. Amabile T.M., 1996. Creativity in context, CO: Westview Press, Boulder. 
3. Amabile T.M.,1988. A model of creativity and innovation in organizations. In: M. Staw \& L.L. Cummings, Eds. Research in organizational behavior. Greenwich: CT: JAI Press, pp. 123-167.

4. Amabile T.M., Khaire M., 2008. Creativity and the role of the leader. Harvard Business Review, October.

5. Andriopoulos C., Dawson P., 2011. Managing Change, Creativity and Innovation, London: Sage, Thousand Oaks.

6. Antoszkiewicz J.D., 2008. Innowacje w firmie. Praktyczne metody wprowadzania zmian [Innovations in the company. Practical methods for making changes], Warszawa: Poltext.

7. Augsdorfer P., Bessant J., Möslein K.M., 2012. Discontinuous Innovation, London: Imperial College Press.

8. Bieniok H., 2014. Kreatywność jako źródło nowoczesności i rozwoju przedsiębiorstw [Creativity as a source of modernity and business development], Zeszyty Naukowe Politechniki Ślaskiej, Organizacja i Zarządzanie, vol. 73, pp. 47-58.

9. Bilton C., Cummings S., 2010. Creative strategy. Reconnecting business and Innovation. Chichester: Wiley.

10. Bratnicka K., 2010. Kultura organizacyjna i twórczość w przedsiębiorczych organizacjach-model koncepcyjny [Organizational culture and creativity in entrepreneurial organizations: a conceptual model]. Przeglad Organizacji, no. 11, pp. 3-5.

11. Bratnicka K., 2011. Rola przywództwa w stymulowaniu twórczości w organizacjach [Leadership role in stimulating creativity in organisations], Organizacja i Kierowanie, no. 4, pp. 129-141.

12. Bratnicka K., 2016. Twórcza przedsiębiorczość organizacyjna i efektywność organizacyjna przedsiębiorstwa. Model mediacji równoległej [Creative organizational entrepreneurship and company organizational efficiency. Parallel mediation model], In: K. Krzakiewicz, Sz. Cyfert, Eds. Strategiczny wymiar dynamicznych zdolności polskich przedsiębiorstw [The strategic dimension of the dynamic capabilities of the Polish companies]. Poznań: Wydawnictwo Uniwersytetu Ekonomicznego w Poznaniu, pp. 83-102.

13. Bratnicka K., 2014. Twórczość i innowacyjność w przedsiębiorstwie. Pośrednicząca rola przedsiębiorczości organizacyjnej [Creativity and innovation in the company. Intermediate role of organizational entrepreneurship]. Studia Ekonomiczne, no. 183, pp. $28-37$.

14. Bratnicki M., Bratnicka K., 2011. Strategiczny wybór oparty na twórczości [A strategic choice based on creativity]. Zeszyty Naukowe Uniwersytetu Ekonomicznego w Poznaniu, no. 169, pp. 31-39.

15. Brzeziński M., 2009. Organizacja kreatywna [Creative organisation]. Warszawa: PWN.

16. Brzóska J., Krannich M., 2016. Modele biznesu innowacyjnej energetyki [Business models of innovative energy], Zeszyty Naukowe Uniwersytetu Ekonomicznego w Katowicach, p. Studia Ekonomiczne, no. 280, pp. 7-20.

17. Czakon W., 2017. Tworzenie teorii w naukach o zarządzaniu [Creation of theories in management sciences]. In: A. Sopińska, P. Wachowiak, Eds. Wyzwania współczesnego zarządzania strategicznego [Challenges of contemporary strategic management]. Warszawa: Oficyna Wydawnicza SGH w Warszawie, pp. 143-159. 
18. Damanpour F., Aravind D., 2012. Organizational Structure and Innovation Revisited: From Organic to Ambidextrous Structure, In: M.D. Mumford, Ed. Handbook of Organizational Creativity, London/Waltham/San Diego: Academic Press/Elsevier, pp. 483-513.

19. Dyduch W., Bratnicki M., 2016. Charakterystyki organizacji inteligentnej [Intelligent organisation characteristics]. Studia i Prace Kolegium Zarządzania i Finansów, Zeszyt Naukowy 149 , pp. 9-23.

20. Dyduch W., 2014. Twórcza strategia jako podstawa dla pobudzania innowacyjności i przedsiębiorczości [Creative strategy as a basis for stimulating innovation and entrepreneurship]. In: A. Kaleta, K. Moszkowicz, L. Sołoducho-Pelc, Eds. Zarzadzanie strategiczne w teorii i praktyce [Strategic management in theory and practice]. Prace Naukowe Uniwersytetu Ekonomicznego we Wrocławiu, no. 366. Wrocław: Wydawnictwo Uniwersytetu Ekonomicznego we Wrocławiu, pp. 108-118.

21. Dyduch W., 2013. Twórcza strategia organizacji [Creative strategy of the organisation]. Katowice: Wydawnictwo Uniwersytetu Ekonomicznego w Katowicach.

22. Kuhn R.L., 1989. Creativity and Strategy in Mid-Sized Firms, New Jersey: Prentice-Hall.

23. Leigh K.E., 2011. Organizational Creativity: The Relationship Between Creativity, Values and Performance in Architectural Practice. Ann Arbor: UMI, ProQuest.

24. Nęcka E., 2005. Psychologia twórczości [Psychology of creativity]. Gdańsk: Gdańskie Wydawnictwo Psychologiczne.

25. Niedzielski P., Rychlik K., 2006. Innowacje i kreatywność [Innovations and creativity]. Szczecin: Wydawnictwo Uniwersytetu Szczecińskiego.

26. Nogalski B., Niewiadomski P., 2016. Twórczość jako domena elastyczności przedsiębiorstwa wytwórczego - próba jej oceny w sektorze maszyn rolniczych [Creativity as the domain of manufacturing company flexibility - attempt to its evaluation in the agricultural machinery sector], Studia Ekonomiczne, no. 280, pp. 116-131.

27. Nogalski B., Szpitter A., Jabłoński M., 2016. Perspektywa wartości sieciowego modelu biznesu jako punkt wyjścia do kształtowania elastycznych modeli biznesu w sektorze energetycznym [The perspective of the business network model value as a starting point for shaping the business flexible models in the energy sector]. In: J. Rokita, Ed. Kompetencje - Modele biznesu - Strategie [Competences - Business models - Strategies]. Katowice: Wyższa Szkoła Handlowa im. Wojciecha Korfantego.

28. Nogalski B., Szpitter A., 2014. Koncepcja sustainability jako determinanta rozwoju przedsiębiorstwa [The concept of sustainability as a determinant of the company development]. In: I. Hejduk, A. Herman, Eds. Zarządzanie dla przyszłości [Management for the future]. Warsaw: Difin, pp. 197-210.

29. Romanowska M., 2016. Badawczy wymiar nauk o zarządzaniu [The research dimension of management sciences] In: G. Osbert-Pociecha, S. Nowosielski, Eds. Meandry teorii i praktyki zarządzania [Meanders of management theory and practice]. Wrocław: Wydawnictwo Uniwersytetu Ekonomicznego we Wrocławiu, pp. 214-222.

30. Romanowska M., 2014. Granice organizacji [Organisation borders]. In: M. Romanowska, J. Cygler, Eds. Granice zarządzania [Management borders]. Warszawa: Oficyna Wydawnicza SGH w Warszawie, pp. 89-97. 
31. Szpitter A., 2010. Zarządzanie innowacjami [Management of innovations]. In: M. Czerska, A. Szpitter, Eds. Koncepcje zarzadzania [Management concepts]. Warszawa: Wydawnictwo C.H. Beck, pp. 351-366.

32. Wachowiak P., Gregorczyk S., Majewski B., 2014. Konflikty w polskich organizacjach [Conflicts in the Polish organisations]. In: P. Wachowiak, S. Winch, Eds. Granice w zarzadzaniu kapitałem ludzkim [Limits in human capital management]. Warszawa: Oficyna Wydawnicza SGH w Warszawie, pp. 363-374. 